\title{
Field-Scale Evaluation of Biosolids-Derived Organomineral Fertilisers Applied to Ryegrass (Lolium perenne L.) in England
}

\author{
Diogenes L. Antille, ${ }^{1,2}$ Ruben Sakrabani, ${ }^{1}$ and Richard J. Godwin ${ }^{3}$ \\ ${ }^{1}$ School of Applied Science, Cranfield University, Cranfield, Bedfordshire MK43 0AL, UK \\ ${ }^{2}$ National Centre for Engineering in Agriculture, University of Southern Queensland, \\ Building Z2, West Street, Toowoomba, QLD 4350, Australia \\ ${ }^{3}$ Harper Adams University, Newport, Shropshire TF10 8NB, UK \\ Correspondence should be addressed to Diogenes L. Antille; Dio.Antille@usq.edu.au
}

Received 3 August 2013; Accepted 11 September 2013

Academic Editor: Rodrigo Studart Corrêa

Copyright (C) 2013 Diogenes L. Antille et al. This is an open access article distributed under the Creative Commons Attribution License, which permits unrestricted use, distribution, and reproduction in any medium, provided the original work is properly cited.

\begin{abstract}
A field-scale experiment was conducted to compare the suitability of two organomineral fertiliser (OMF) formulations $\left(\mathrm{OMF}_{10}-\right.$ $10: 4: 4$ and $\left.\mathrm{OMF}_{15}-15: 4: 4\right)$ with urea and biosolids granules applied to perennial ryegrass. Results showed a $25 \%$ to $30 \%$ increase in dry matter yield (DMY) with application of OMF compared with biosolids granules but about $5 \%$ lower than urea. For OMF, an average input of $0.8 \times \mathrm{N}_{\max }$ yielded $0.98 \times \mathrm{DMY}_{\max }$ which was similar to that of urea; whereas, for biosolids, a yield of $0.92 \times \mathrm{DMY}_{\max }$ required an input of $0.6 \times \mathrm{N}_{\max }$ but DMY was lower $(P<0.05)$. Agronomic efficiencies with OMF were in the range of 26 to $35 \mathrm{~kg}$ $\mathrm{kg}^{-1}$, approximately double those of biosolids but about $5 \%$ to $10 \%$ lower than urea. Soil extractable P levels remained close to constant; therefore, soil P Index was not affected by OMF application. This result supported the reasons for the proposed OMF formulations and demonstrated the advantage of the products compared with biosolids which induced an increase $(P>0.05)$, in soil extractable P. The application of OMF at rates which do not exceed the optimum $\mathrm{N}$ rate for the grass crop should not induce significant changes in soil P Index including application to soils with satisfactory P levels. OMF application strategies are discussed which will enable minimising environmental concerns and maximising fertiliser use efficiency.
\end{abstract}

\section{Introduction}

In Europe, the gradual implementation of the Urban Waste Water Treatment Directive 91/271/EEC [1] has resulted in increasing amounts of sewage sludge that require safe disposal [2]. Estimates for 2005 indicated that the European community produces approximately 9 million tonnes per year of sewage sludge (dry solids) which represents an increment of about $65 \%$ compared with the level recorded in 1992 [2]. The use of tertiary treatment for the removal of nutrients from wastewater is a requirement in sensitive areas before treated water is recycled to the environment [3]. Therefore, further requirements for enhanced treatment of sewage effluents can arise from future designations of sensitive waters under the provision of the Directive [1] which will result in increased sludge production. Edge [4] estimated that phosphorus removal by precipitation increases sludge production by about $10 \%$ to $25 \%$ compared with sludge that receives secondary treatment only.

In England, the water industry recognises significant cost advantages in recycling biosolids through agriculture compared with alternative more expensive disposal options such as landfill and incineration. Estimates (Antille [5] with 2007 figures) indicated that agricultural recycling costs wastewater companies approximately 150 GBP per tonne of raw sludge (dry solids) including finance and depreciation and that landfill and incineration are about 35\% and 60\% more expensive, respectively. The latter two disposal options are regarded as less sustainable practices [6], therefore, being increasingly restricted by environmental legislation [7] such as the EU Landfill Directive 99/31/EC [8]. Specifically for the NW region of England, the disposal strategy of wastewater operators is based upon a dual approach of recycling to 
farmland and incineration representing, approximately, 70\% and $30 \%$ of the total sludge production, respectively [5]. The relatively high reliance on recycling means that the agricultural route for disposal needs to be protected by maintaining, or where possible increasing, existing levels of biosolids uptake by farmers. However, this presents wastewater companies with a number of challenges, such as those indicated in earlier studies for example, [9-11], which combine to restrain the agricultural route as well as the opportunities to increase recycling targets in the longer term. One possible way to increase recycling levels is by improving the quality of biosolids which can significantly minimise environmental concerns, enhance their agronomic performance, and therefore secure the agricultural route $[5,12]$. The focus on product quality, needed for increased acceptance of biosolids, requires a cultural shift within wastewater management companies.

The need to increase agricultural production to sustain a growing population requires the development of sustainable technologies to ensure that food supply is not affected [13, 14]. In the UK, some of the challenges associated with food security, sustainability, and health are being addressed following the launch of the Food Strategy 2030 [15]. Dawson and Hilton [16] recognised that increased food production will bring about increased demand for mineral fertilisers. A more stable fertiliser demand may be achieved by improving the efficiency of nutrient management from organic materials recycled to land, combined with increased levels of recycling of these materials. Fischer et al. [17] acknowledged that there is a synergism amongst sustainable technologies which enables achieving not only greater yields but also greater resource efficiency.

Technology is available for the production of organomineral fertilisers (OMF) which can be obtained by coating biosolids granules with urea $(46 \% \mathrm{~N})$ and potash $(60 \%$ $\mathrm{K}_{2} \mathrm{O}$ ) to provide a balanced compound fertiliser with suitable physical characteristics $[5,18]$. This product concept appears to be a sustainable approach to recycling biosolids to agriculture, and it aims to increase current levels of uptake by farmers by offering an enhanced organic-based fertiliser material. The coating technology used in the production of OMF enables the concentration of nutrients in the granules to be adjusted to meet specific soil-crop requirements [5, 18]. The development of such product requires evaluation at the field-scale to determine if the perceived agronomic, environmental, and economic benefits can be effectively delivered.

The aim of this work was to assess the agronomic efficiency and the effects on selected soil chemical properties, especially those related to potential build-up of soil $\mathrm{P}$, of two organomineral fertilisers (OMF) which were applied to a grass crop (Lolium perenne L.) in a field-scale trial during 2009 and 2010. The OMF are referred to as $\mathrm{OMF}_{10}$ and $\mathrm{OMF}_{15}$, and have $\mathrm{N}: \mathrm{P}_{2} \mathrm{O}_{5}: \mathrm{K}_{2} \mathrm{O}$ compositions $15: 4: 4$ and $10: 4: 4$ respectively, $[5,18]$. It was hypothesised that: (1) DMY of the grass crop amended with OMF would be comparable to that of urea but higher than biosolids-treated crop and (2) soil P levels would not change significantly as a result of OMF application and therefore soil P Index would remain close to constant. The results reported in this study

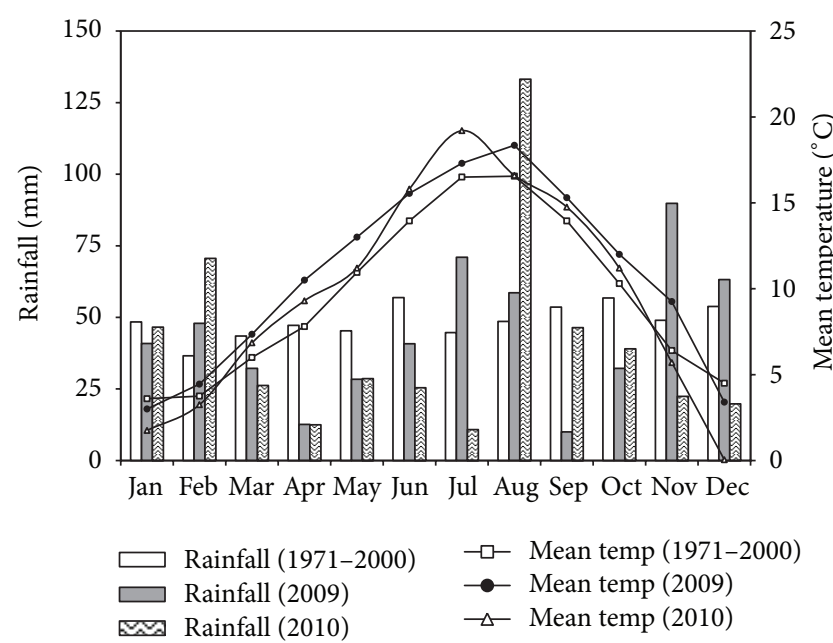

FIGURE 1: Rainfall and temperature records for Silsoe, Bedfordshire, UK [19].

aided the development of a set of practical recommendations concerning the use of OMF in grass crops.

\section{Materials and Methods}

2.1. Experimental Site. An experimental site was established at Cranfield University, Silsoe $\left(52^{\circ} 00^{\prime} 19^{\prime \prime} \mathrm{N}, 0^{\circ} 25^{\prime} 36^{\prime \prime} \mathrm{W}\right)$ located in Bedfordshire, England, in February 2009. The site had been occupied by a first (2006-2007) and a second (20072008) winter wheat (Triticum aestivum L.) crops prior to the start of the experiment. The meteorological records for the site are shown in Figure 1 [19].

The soil type within the field is a Cottenham series sandy loam [20] which has $67 \%$ sand, $13 \%$ clay, and $20 \%$ silt [21]. The soil is well drained with a gentle slope $(<1 \%)$. Field capacity determined at 0.05 bar reported a moisture content equivalent to $26.6 \%\left(\mathrm{w} \mathrm{w}^{-1}\right)$ [21]. The mean annual rainfall recorded for the period 2009 to 2010 was $505 \mathrm{~mm}$, about $15 \%$ lower compared to historic records (from 1971 to 2000) [19]. Air temperatures in the spring and summer of 2009 and 2010 were above the historic average. Smith and Trafford [22] reported that Area 28 (Cambridgeshire and Bedfordshire, England) is characterised by a mean excess winter rain of $130 \mathrm{~mm}$ which allows the soil to return to field capacity around 10 December. This soil condition ends around 27 March but usually not later than 19 April. Mean soil moisture deficits of up to $85 \mathrm{~mm}$ and $103 \mathrm{~mm}$ typically occuring at the end of June, and at the end of July respectively [22]. The experimental site was marked out to comprise 60 plots (plot dimensions: $2 \mathrm{~m} \times 5 \mathrm{~m}$ ) which were georeferenced using a Leica ATX-1230 Smart Rover apparatus to facilitate their repositioning in subsequent years.

2.2. Grass Crop. The grass crop was drilled on March 30, 2009 at a rate of $1.5 \mathrm{~kg}$ of seeds per ha and emergence recorded on April 11, 2009. A commercially available grass mix (15\% Molisto, 30\% Gandalf, 30\% Premium, and 25\% Fornax) of 
perennial ryegrass (Lolium perenne L.) was used. Broadleaves weeds were chemically controlled in postemergence with a conventional herbicide following standard farm practices. The grass was harvested manually using a $0.5 \mathrm{~m}^{2}$ quadrate which was placed approximately in the center of the plots and the grass was cut at $20 \mathrm{~mm}$ above the soil surface three times in 2009 (14 July, 25 August and 21 October) and two times in 2010 (17 April and 20 June). The harvested plant material was oven-dried at 60 degrees Celsius for 48 hours [23] to determine dry matter yield (DMY) which is reported in $\mathrm{kg}$ of dry matter (DM) per hectare. After each harvest, the entire experimental site was mechanically cut to about the same height $(20 \mathrm{~mm})$ to ensure that the regrowth of the grass sward was uniform both in and between plots.

Yield-to-nitrogen response curves were examined by applying nonlinear regression analyses [24]. Quadratic functions (1) were fitted to the data from which the maximum (2) and the optimum (3) dry matter yields were derived [25]. Consider

$$
y=a+b x-c x^{2},
$$

where $a, b$, and $c$ are regression coefficients, " $x$ " is the nitrogen application rate, and " $y$ " is dry matter yield (DMY). Consider

$$
\begin{aligned}
& \mathrm{DMY}_{\max }\left(\frac{d y}{d x}=0\right), \\
& \mathrm{DMY}_{10}\left(\frac{d y}{d x}=10\right),
\end{aligned}
$$

where $\mathrm{DMY}_{\max }$ and $\mathrm{DMY}_{10}$ are the maximum and the optimum dry matter yields $\left(\mathrm{kg} \mathrm{ha}^{-1}\right)$, respectively. $\mathrm{DMY}_{\max }$ is equivalent to the potential harvestable yield given the climatic and soil condition, and subjected to the particular crop and fertiliser management practices [25]. DMY 10 is the yield at which the response of the grass crop equates to $10 \mathrm{~kg}$ of $\mathrm{DM}$ per $\mathrm{kg}$ of $\mathrm{N}$ added. The nitrogen application rates $(\mathrm{kg}$ $\mathrm{ha}^{-1}$ ) required for $\mathrm{DMY}_{\max }$ and $\mathrm{DMY}_{10}$ are $\mathrm{N}_{\max }$ and $\mathrm{N}_{10}$, respectively.

The agronomic efficiency of the $\mathrm{N}$ applied with the fertilisers (4) was obtained using the difference method [26, 27]. This parameter was calculated for the optimum dry matter yield $\left(\mathrm{DMY}_{10}\right)$ and the corresponding $\mathrm{N}$ application rate $\left(\mathrm{N}_{10}\right)$, and it is reported in $\mathrm{kg}$ of $\mathrm{DM}$ per $\mathrm{kg}$ of $\mathrm{N}$. Consider

$$
\text { Agronomic efficiency }=\frac{\mathrm{DMY}_{10}-\mathrm{DMY}_{\text {Control }}}{\mathrm{N}_{10}},
$$

where $\mathrm{DMY}_{\text {Control }}$ is the mean dry matter yield corresponding to the unfertilised control.

2.3. Fertiliser Treatments. The experiment was subjected to the following treatments: two organomineral fertilisers (OMF), referred to as $\mathrm{OMF}_{15}(15: 4: 4)$ and $\mathrm{OMF}_{10}(10: 4: 4)$ $[5,18]$, were compared with a mineral fertiliser (urea, $46 \% \mathrm{~N}$ ) and biosolids granules; the latter material had the following $\mathrm{N}: \mathrm{P}_{2} \mathrm{O}_{5}: \mathrm{K}_{2} \mathrm{O}$ compositions: $4: 6.6: 0.1$ and $5.5: 4.3: 0.2$ for the batches corresponding to 2009 and 2010, respectively
$[5,18]$. The fertilisers materials were hand-applied in a single dressing at rates ranging from 0 (control) to $250 \mathrm{~kg} \mathrm{ha}^{-1}$ of $\mathrm{N}$ at regular increments of $50 \mathrm{~kg} \mathrm{ha}^{-1}$ of $\mathrm{N}$. There were two fertiliser applications which were conducted on June 10, 2009 and April 18, 2010, respectively. In 2010, the fertiliser application was conducted after the first cut of the grass to assess residual effects of OMF-N and biosolids-N on DMY up to this cut. This was justified given the relatively slow mineralisation rate of the organic- $\mathrm{N}$ fraction contained in OMF and biosolids granules [21]. Under the UK conditions, mineralisation of biosolids- $\mathrm{N}$ and organic OMF-N is likely to continue well after the harvest of winter cereal crops when these materials are applied in early spring [21]. Therefore, $\mathrm{N}$ carried over into the autumn and winter, if not lost by leaching or gaseous evolution, can influence DMY levels in the first cut the following year which needed to be assessed.

2.4. Soil Analyses. Soil was sampled to a depth of $150 \mathrm{~mm}$ [28] and analysed using standard laboratory techniques. Soil sampling was conducted prior to the start of the experiment to determine background levels and routinely thereafter. The following analyses were conducted: total $\mathrm{N}$ in soil [29], soil extractable P [30, 31], soil exchangeable K [23] (Method no.: 63), soil pH [23] (Method no.: 32), soil organic matter (SOM) [23] (Method no.: 56), and soil mineral N (SMN) [23] (Method no.: 53). For soil exchangeable K, analyses were conducted for the control (zero fertiliser) and the treatments that received 150 and $250 \mathrm{~kg} \mathrm{ha}^{-1}$ of N. Analyses of soil extractable $P$ and exchangeable K enabled examining changes in soil $\mathrm{P}$ and $\mathrm{K}$ Indexes, respectively, that occurred as a result of the fertiliser treatment. Soil $\mathrm{P}$ and $\mathrm{K}$ Indexes are defined in DEFRA [28] and analytical values are expressed in $\mathrm{mg} \mathrm{L}^{-1}$. A soil bulk density value of $1.34 \mathrm{~g} \mathrm{~cm}^{-3}$ was used to convert from $\mathrm{mg} \mathrm{L}^{-1}$ to $\mathrm{mg} \mathrm{kg}^{-1}$ [21].

2.5. Statistical Analyses. Statistical analyses were undertaken using GenStat 14th Edition [32]. For dry matter yield (DMY), analyses involved ANOVA and LSD test $(P<0.05)$. For the measured soil chemical properties, analyses involved repeated measurement of analysis of variance $(P<0.05)$ which enabled factoring in the effect of the time. The experiment used a completely randomised design, and all treatments were replicated three times $(n=3)$ except for the controls (zero fertiliser) and the plots treated with $250 \mathrm{~kg} \mathrm{ha}^{-1}$ of $\mathrm{N}$ which were replicated four $(n=4)$ and two $(n=2)$ times, respectively. This arrangement enabled fitting all plots within the designated experimental area and minimising the interference with the surrounding commercial crop in the field.

\section{Results and Discussion}

3.1. Dry Matter Yield and Crop Responses. Figure 2 shows dry matter yields (DMY) of the grass crop as affected by fertiliser treatment in 2009 and 2010, respectively. In both years, there were significant differences in total (annual) DMY between the control and the treatments $(P<0.001)$. The differences in DMY were significant with respect to the 
fertiliser type and the $\mathrm{N}$ application rate $(P$ values $<0.001)$. The interaction fertiliser type $\times \mathrm{N}$ application rate was not significant $(P$ values $>0.05)$. On average across all treatments, the application of fertiliser increased DMY by about $80 \%$ in 2009 and approximately three times in 2010 compared with the controls. There was a positive response of DMY to the concentration of $\mathrm{N}$ in the fertiliser material, in particular, the concentration of readily available $\mathrm{N}$. The first cut conducted in 2010 resulted in DMY levels in the range of 680 to $920 \mathrm{~kg}$ $\mathrm{ha}^{-1}$ of DM across all treatments which were not significantly different for an LSD value (5\% level) of $388 \mathrm{~kg} \mathrm{ha}^{-1}$ of DM. These results confirmed that the residual effect of the fertiliser applied in the previous year was relatively small and of similar magnitude across all treatments. Hence, it is possible to suggest that losses of $\mathrm{N}$ via leaching or gaseous evolution from fertiliser-treated plots had occurred following the third cut in 2009.

The functions used to describe the responses of the grass crop to the application of $\mathrm{N}$ showed acceptable fits to quadratic models, and the terms derived from these responses produced reasonable solutions (Table 1). Linear relationships were also possible since the estimates of parameters were significant $(P$ values $<0.05)$ for the linear term in all cases. The responses of the grass crop to the application of biosolids did not produce a significant effect for the square term of the quadratic function which was observed in both years $(P$ values $>0.05)$. Hence, the dry matter yield-tonitrogen response curve for biosolids may be better explained by a linear function instead. However, since the coefficients of the square term were negative, there was an indication that, under the prevailing experimental conditions, DMY started to decline above certain level of $\mathrm{N}$ fertilisation. Therefore, the use quadratic functions to describe these responses may be justified which also enabled deriving the maximum $\left(\mathrm{DMY}_{\max }\right)$ and the optimum dry matter yields $\left(\mathrm{DMY}_{10}\right)$ respectively.

The responses to the application of $\mathrm{OMF}_{10}, \mathrm{OMF}_{15}$, and urea showed average increments in DM (range of 21 to $31 \mathrm{~kg} \mathrm{DM} \mathrm{kg}^{-1} \mathrm{~N}$ ) which were within the range (14 to $29 \mathrm{~kg}$ $\mathrm{DM} \mathrm{kg}{ }^{-1} \mathrm{~N}$ ) reported by Morrison [25] but exceeded those encountered by McFeely and MacCarthy [33] and O'Donovan et al. [34] (range of 5 to $17 \mathrm{~kg} \mathrm{DM} \mathrm{kg}^{-1} \mathrm{~N}$ ). The responses obtained were related to the concentration of readily available $\mathrm{N}$ in the fertiliser. Biosolids showed average increments in DM per additional unit of $\mathrm{N}$ which were between $16 \%$ and $30 \%$ lower than OMF or urea. Differences between fertilisers were smaller in 2010 which responded to the combined effect of drier soil conditions in the early part of the spring (Figure 1) and the surface application of the fertilisers. This effect was observed despite that the timing of fertiliser application matched, approximately, the expected peak of growth of the grass crop which under the UK conditions typically occurs around May [35]. The relatively dry and warm conditions recorded in April 2010 (Figure 1) support the possibility of $\mathrm{N}$ losses by volatilisation of $\mathrm{NH}_{3}$ after the fertiliser application. For urea-containing fertilisers, these losses are enhanced at higher $\mathrm{N}$ application rates or with increased temperature (range of $10^{\circ} \mathrm{C}$ to $30^{\circ} \mathrm{C}$ ) [36].
The values of $\mathrm{N}_{\max }$ obtained for biosolids granules (Table 1) should be treated with caution as they resulted from extrapolating data that falls outside the range of $\mathrm{N}$ application rates used in this study, that is, from 0 to $250 \mathrm{~kg} \mathrm{ha}^{-1}$ of $\mathrm{N}$. These $\mathrm{N}_{\max }$ values however reflect the linearity of the responses of the grass treated with biosolids granules. In 2010, the grass treated with $\mathrm{OMF}_{15}$ marginally outperformed that treated with urea, but differences between the two fertiliser sources were not significant $\left(\right.$ LSD 5\% level $=525 \mathrm{~kg} \mathrm{ha}^{-1}$ of DM). The same was observed for the other parameters derived from the response curves as $\mathrm{OMF}_{15}$-treated grass required slightly less $\mathrm{N}$ for both maximum $\left(\mathrm{DMY}_{\max }\right)$ and optimum $\left(\mathrm{DMY}_{10}\right)$ yields. This was due to weather conditions recorded in the early part of the spring in 2010 (Figure 1), especially, the lack of rainfall during April which accounted for a total of $8.2 \mathrm{~mm}$ [19].

The $\mathrm{N}_{10}$ values showed in Table 1 indicate the $\mathrm{N}$ application rates above which the response of the grass crop is less than $10 \mathrm{~kg} \mathrm{ha}^{-1}$ of dry matter. This value is considered to be an adequate lower limit of response from the agronomic and environmental perspectives [25]. For all fertiliser types, the calculated values of $\mathrm{N}_{10}$ were approximately within the range of $\mathrm{N}$ application rates recommended for grass (cut) in England [28] in situations with moderate to high soil $\mathrm{N}$ supply. These $\mathrm{N}_{10}$ values are also in close agreement with those obtained by Morrison et al. [25] (range of 183 to $300 \mathrm{~kg}$ $\mathrm{ha}^{-1}$ of $\mathrm{N}$ ) for more than 20 experimental sites scattered across England and Wales. In situations where soil $\mathrm{N}$ supply is low or where more than three cuts are performed during the main growing season (April to September), the use of a straight $\mathrm{N}$ source may be recommended after the second cut. Based on the general guidelines given for England in RB209 [28], N application rates for individual cuts should not exceed $120 \mathrm{~kg} \mathrm{ha}^{-1}$. For OMF, this is an important consideration given that it contains urea which is prone to volatilisation at high $\mathrm{N}$ application rates [36]. For the first cut, which is typically the one that requires the highest $\mathrm{N}$ dressing (e.g., up to $120 \mathrm{~kg} \mathrm{ha}^{-1}$ of N), apply about $30 \%$ to $40 \%$ between the middle of February and early March with the balance in late March to early April allowing a minimum of six weeks before the cut. For subsequent cuts, $\mathrm{N}$ should be applied immediately after the previous cut but, because the $\mathrm{N}$ rates are usually lower than $120 \mathrm{~kg} \mathrm{ha}^{-1}$, the full dressing may be applied. Because of the characteristics patterns of growth of grass swards under the climatic conditions of the UK [35], this fertilisation strategy will maximise the response of the grass to the application of fertiliser-N, including OMF-N, and will minimise the opportunities for $\mathrm{N}$ losses to the environment $[5,28]$. In 2009, the recommendations regarding the timing of fertiliser application could not be strictly followed because it was the year of grass establishment and emergence was recorded on 11 April.

For $\mathrm{OMF}_{10}$ and $\mathrm{OMF}_{15}$, an average input of about $0.8 \times$ $\mathrm{N}_{\max }$ yielded $0.98 \times \mathrm{DMY}_{\max }$ which was similar to that of urea, whereas, for biosolids, a yield of $0.92 \times \mathrm{DMY}_{\max }$ required an input of $0.6 \times \mathrm{N}_{\max }$ but DMY was significantly lower $(P<0.05)$. The agronomic efficiencies of the fertilisers applied reflect an improved performance of the grass crop 
TABLE 1: Parameters derived from the response of the grass crop to the application of fertiliser-N in 2009 and 2010.

\begin{tabular}{|c|c|c|c|c|c|c|c|c|c|c|}
\hline $\begin{array}{l}\text { Parameter } \\
\text { Unit }\end{array}$ & $\begin{array}{c}\text { Mean DMY } \\
\mathrm{kg} \mathrm{ha}^{-1}\end{array}$ & $\begin{array}{c}\mathrm{SD} \\
\mathrm{kg} \mathrm{ha}^{-1}\end{array}$ & $\begin{array}{c}\text { Response } \\
-\end{array}$ & $\begin{array}{c}P \text { value } \\
-\end{array}$ & $\begin{array}{l}\mathrm{R}^{2} \\
-\end{array}$ & $\begin{array}{l}\mathrm{DMY}_{\max } \\
\mathrm{kg} \mathrm{ha}^{-1}\end{array}$ & $\begin{array}{l}\mathrm{N}_{\max } \\
\mathrm{kg} \mathrm{ha}^{-1}\end{array}$ & $\begin{array}{l}\mathrm{DMY}_{10} \\
\mathrm{~kg} \mathrm{ha}^{-1}\end{array}$ & $\begin{array}{c}\mathrm{N}_{10} \\
\mathrm{~kg} \mathrm{ha}^{-1}\end{array}$ & $\begin{array}{c}\text { Agronomic efficiency } \\
\mathrm{kg} \mathrm{kg}^{-1}\end{array}$ \\
\hline Treatment & & & & & 2009 & & & & & \\
\hline Control & $6188^{\mathrm{a}}$ & 126 & - & - & - & - & - & - & - & - \\
\hline Biosolids & $9285^{\mathrm{b}}$ & 1389 & $y=6406+24.6 x-0.03 x^{2}$ & $<0.001$ & 0.74 & 11986 & 455 & 11060 & 270 & 18.0 \\
\hline $\mathrm{OMF}_{10}$ & $11270^{c}$ & 1330 & $y=6576+53.8 x-0.12 x^{2}$ & $<0.001$ & 0.87 & 12460 & 219 & 12255 & 180 & 33.7 \\
\hline $\mathrm{OMF}_{15}$ & $11958^{\mathrm{d}}$ & 1643 & $y=6547+56.9 x-0.11 x^{2}$ & $<0.001$ & 0.94 & 13798 & 255 & 13574 & 210 & 35.2 \\
\hline Urea & $12230^{\mathrm{d}}$ & 1778 & $y=6586+60 x-0.12 x^{2}$ & $<0.001$ & 0.89 & 14027 & 248 & 13820 & 207 & 36.9 \\
\hline Treatment & & & & & 2010 & & & & & \\
\hline Control & $2192^{\mathrm{a}}$ & 204 & - & - & - & - & - & - & - & - \\
\hline Biosolids & $5394^{\mathrm{b}}$ & 1287 & $y=2435+26.6 x-0.04 x^{2}$ & $<0.001$ & 0.78 & 7266 & 364 & 6581 & 227 & 14.1 \\
\hline $\mathrm{OMF}_{10}$ & $6624^{\mathrm{c}}$ & 1080 & $y=2532+46.9 x-0.11 x^{2}$ & $<0.001$ & 0.90 & 7651 & 218 & 7418 & 172 & 25.8 \\
\hline $\mathrm{OMF}_{15}$ & $7385^{\mathrm{d}}$ & 1266 & $y=2396+63.6 x-0.17 x^{2}$ & $<0.001$ & 0.92 & 8500 & 192 & 8348 & 162 & 32.1 \\
\hline Urea & $7357^{\mathrm{d}}$ & 1240 & $y=2523+58.4 x-0.14 x^{2}$ & $<0.001$ & 0.90 & 8477 & 204 & 8302 & 170 & 30.4 \\
\hline
\end{tabular}

Mean DMY is annual dry matter yield across all $N$ application rates, and SD is the standard deviation. For mean DMY, different letters indicate values that are significantly different at a $95 \%$ confidence interval.

treated with $\mathrm{OMF}_{10}, \mathrm{OMF}_{15}$, and urea relative to that of biosolids granules as well as differences in their relative effectiveness between years. In the drier year (2010), the efficiency of biosolids $\mathrm{N}$ was affected by lower microbial activity which reduced the mineralisation rate of organic $\mathrm{N}$ in the material. For OMF and urea water shortages translated into greater $\mathrm{N}$ losses by volatilisation of $\mathrm{NH}_{3}$, hence, reduced $\mathrm{N}$ availability to the grass crop and reduced $\mathrm{N}$ uptake [36] which is reflected in the relatively lower agronomic efficiencies obtained for these materials in the second year.

\subsection{Soil Analyses}

3.2.1. Nitrogen in Soil. The controls (zero fertiliser) did not show significant differences in total $\mathrm{N}$ in soil compared with the treatments at the end of the experiment $(P=0.06)$. However, there were significant differences $(P<0.001)$ both in the control plots and the treatments compared with the initial levels of total $\mathrm{N}$ in soil recorded at the start of the experiment (Figure 3). The effects of the fertiliser type or $\mathrm{N}$ application rate on total $\mathrm{N}$ in soil were not significant $(P$ values $>0.05$ ) which suggested that there was an effect of the grass crop that masked differences between control and treatments.

The increase in total $\mathrm{N}$ in the control plots compared with the initial level was attributed to restricted crop growth and therefore reduced $\mathrm{N}$ uptake in the absence of $\mathrm{N}$ fertilization and the effect of mulching which returned organic matter to the soil after each cut. The soil treated with biosolids reported relatively higher values compared with the control and the other treatments (Figure 3 ) but the overall effect of the fertiliser type was not significant $(P>0.05)$. However, analytical results suggested that differences in total $\mathrm{N}$ in soil between biosolids and the other fertiliser treatments would be greater in the longer term because of the slow mineralisation rate of organic biosolids- $\mathrm{N}$ [21]. Therefore, it is suggested that total $\mathrm{N}$ in soil is monitored when routine applications of biosolids are conducted as part of the fertilisation plan as this will affect soil $\mathrm{N}$ supply in subsequent years and consequently fertiliser$\mathrm{N}$ recommendations. Sylvester-Bradley [37] suggested that there is scope for reducing $\mathrm{N}$ fertilisation if soil $\mathrm{N}$ supply could be accurately predicted for the main growing season. However, its estimation based on soil mineral N (SMN) did not appear to be a reliable approach in this study since the overall differences between control and treatments were not significant $(P=0.21)$. There was an effect of the fertiliser type $(P=0.02)$ on SMN levels which was due to marginally higher values recorded in urea-treated plots compared with the other treatments. However, SMN values were generally low across all fertiliser treatments and rarely exceeding $5 \mathrm{mg}$ $\mathrm{kg}^{-1}$ as determined annually before the fertiliser application and after the last cut of the grass crop. The ample period of growth of the grass crop, hence $\mathrm{N}$ uptake, combined with a relatively slow mineralisation rate of organic- $\mathrm{N}$ in $\mathrm{OMF}$ and biosolids [21] explain the results obtained in this set of analyses.

3.2.2. Soil Extractable Phosphorus. The control and the treatments reported a soil P Index 5 which equates to Olsen's P in the range of 71 to $100 \mathrm{mg} \mathrm{L}^{-1}$ [28]. Figure 4 shows that, overall, there were no significant differences in soil extractable $P$ between the control and the treatments $(P=0.92)$ but there was a significant effect of the fertiliser type $(P=0.01)$. This effect was due to the relatively higher soil extractable $\mathrm{P}$ value recorded in biosolids-treated plots compared with those treated with $\mathrm{OMF}_{10}, \mathrm{OMF}_{15}$, and urea. The application of OMF did not change soil extractable P levels significantly compared with the unfertilised control plots; therefore, soil P Index remained unchanged.

The results showed that continuous application of biosolids granules will tend to build up soil extractable $\mathrm{P}$ levels, while the absence of $\mathrm{P}$ fertilisation in urea-treated grass will have the opposite effect (Figure 4). On the contrary, the application of $\mathrm{OMF}_{10}$ and $\mathrm{OMF}_{15}$ maintained soil $\mathrm{P}$ status 
2009

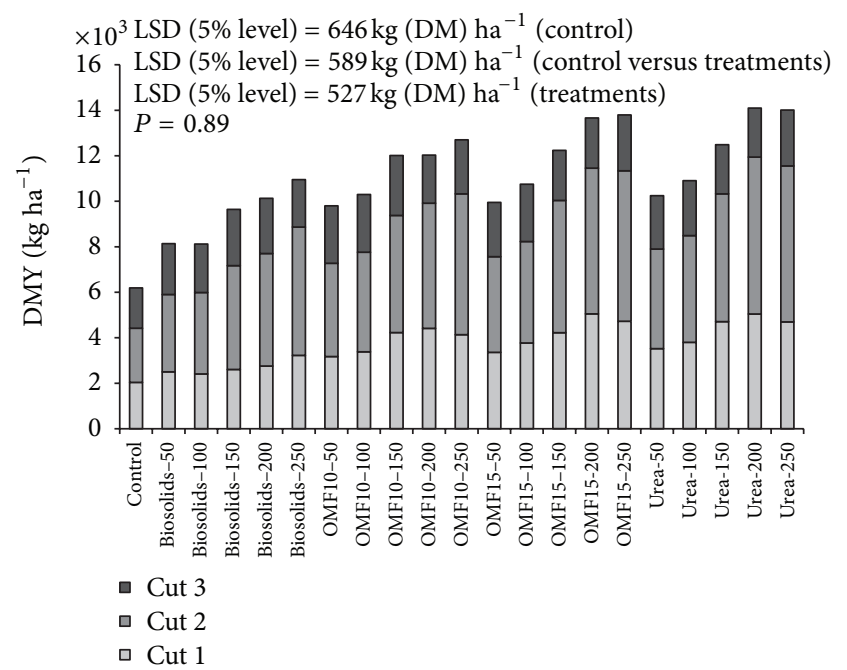

(a)

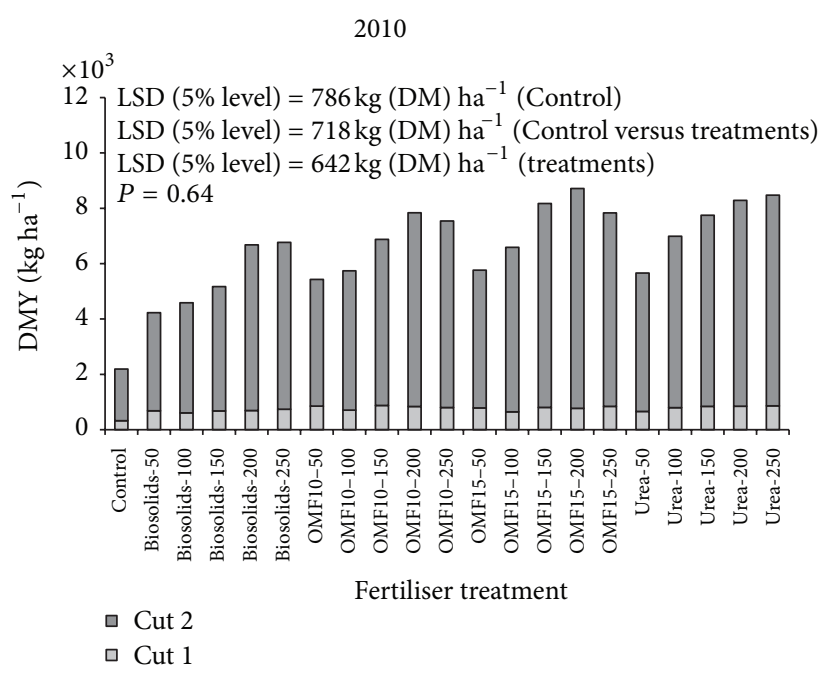

(b)

FIGURE 2: Dry matter yield (DMY) of the grass crop as affected by the fertiliser treatment in 2009 (a) and 2010 (b). The $x$-axis shows the fertiliser type followed by the corresponding $\mathrm{N}$ application rate in $\mathrm{kg}$ per ha. Use $n=4$ (control) and $n=3$ (treatments) except when $\mathrm{N}=250 \mathrm{~kg} \mathrm{ha}^{-1}, n=2$.

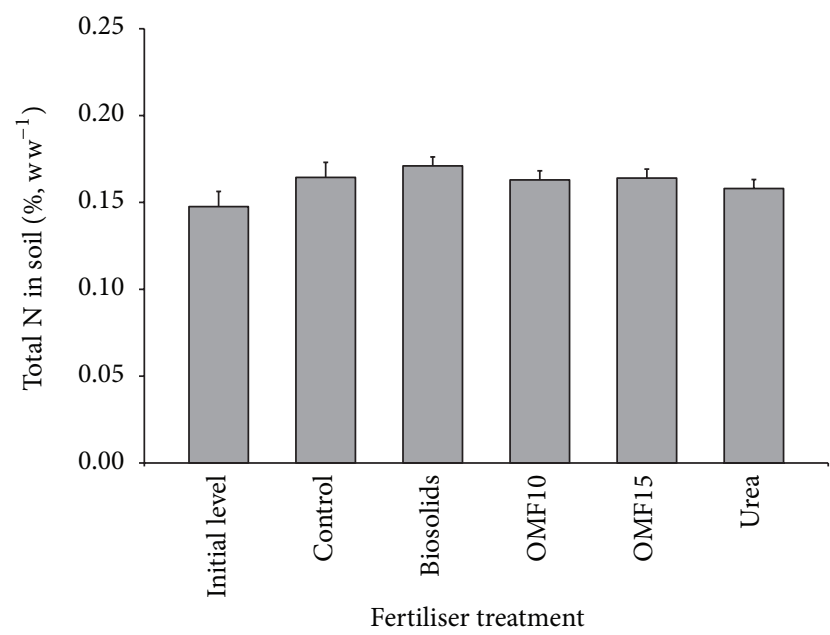

Figure 3: Mean total $\mathrm{N}$ in soil over the range of fertiliser application rates used in the experiment. The initial level corresponds to the baseline level prior to the start of the experiment. Use $n=14$ except for initial level and control $n=3 ; P=0.06$ (control versus treatments), $P=0.91$ (treatments). The error bars show the LSD value at $5 \%$ level.

close to constant which therefore supports the reasons for the proposed OMF formulations $[5,18]$. The importance of these results strives for the need to ensure that soil extractable $\mathrm{P}$ is not increased in those soils which have satisfactory P levels, as defined in DEFRA [28] but that their overall fertility is maintained. The results obtained with biosolids reflected the issue of potential build-up of soil $\mathrm{P}$ when materials with low $\mathrm{N}: \mathrm{P}$ ratio $(\approx 1)$ are applied based on the $\mathrm{N}$ requirements of the crop. They also highlight one of the limitations being faced

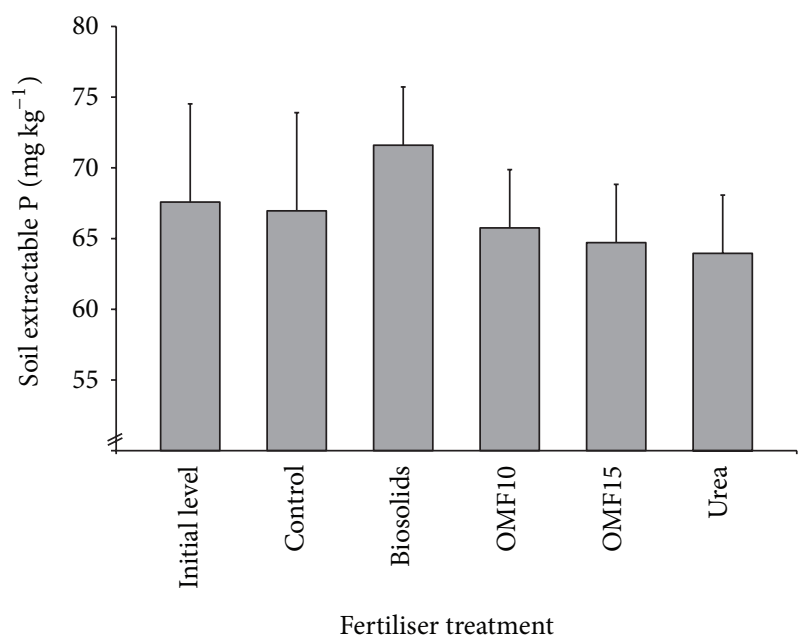

FIgURE 4: Mean soil extractable P over the range of fertiliser application rates used in the experiment. The initial level corresponds to the baseline level prior to the start of the experiment. Use $n=14$ except for initial level and control $n=3 ; P=0.92$ (control versus treatments), $P=0.01$ (treatments). The error bars show the LSD value at $5 \%$ level.

by wastewater operators in England, especially in the NW region, regarding the application of biosolids in agricultural land which has satisfactory soil $\mathrm{P}$ Indexes $[28,38]$. The conversion of sludge into balanced organomineral fertilisers has therefore potential to address this issue and increase recycling targets in areas close to production sites.

The small decline in soil extractable $\mathrm{P}$ in urea-treated plots also responded to the relatively higher DMY obtained with this fertiliser (Table 1) which resulted in enhanced 
$\mathrm{P}$ removal. In soils with adequate $\mathrm{P}$ and $\mathrm{K}$ Indexes [28], avoidance of $\mathrm{P}$ and $\mathrm{K}$ fertilisation may not affect DMY of grass crops in the short term [39]. However, the longterm experiments at Rothamsted in the UK [40] showed that continuous omission of $\mathrm{P}$ and $\mathrm{K}$ application causes reduction in crop yield when the available soil $\mathrm{P}$ and $\mathrm{K}$ reserves have declined below a critical level appropriate for the soil and crop system [39]. Below this level, and due to nutrient interactions, $\mathrm{N}$ use efficiency in grassland soils is significantly affected which has adverse effects both from the economic and environmental perspectives [39, 41, 42]. Since the availability of biosolids- $\mathrm{N}$ is low [21], DMY and P uptake in biosolids-treated crop were restricted by $\mathrm{N}$ supply which contributed to maintaining relatively higher concentrations of $\mathrm{P}$ in the soil solution compared with the other treatments.

Application of OMF-N at rates equivalent to $\mathrm{N}_{10}$ should not increase soil $\mathrm{P}$ Index as the calculated $\mathrm{N}_{10}$ rates are lower than the highest $\mathrm{N}$ application rate $\left(250 \mathrm{~kg} \mathrm{ha}^{-1}\right.$ of $\mathrm{N}$ ) used in this study, which did not result in significant changes in soil P status. On the contrary, the application of OMF at the optimum rate will replenish, approximately, $\mathrm{P}$ off-take by the crop thereby maintaining soil $\mathrm{P}$ levels close to constant over time. Previous studies with OMF under controlled glasshouse conditions [5] showed that P uptake in OMF-treated grass was greater $(P<0.05)$ than that of biosolids granules. The enhanced uptake of $\mathrm{P}$ with the use of a fertiliser material with higher readily available $\mathrm{N}$ content was due to the positive interaction that exists between the two plant nutrients [43]. Reduced P uptake in biosolidstreated grass led to a significant change (increase) in soil extractable P after three years [5]. For OMF-treated grass, the same study showed that soil extractable P levels were not modified significantly $(P>0.05)$ which agrees with the results presented in this article. This occurred despite of the relatively low bioavailability of $\mathrm{P}$ contained in OMF [21]. The application of $\mathrm{P}$ with OMF replenishes the less readily available and the very slowly available soil P pools which overtime are released to the readily available pool and the soil solution, that is, the two fractions measured in routine soil analyses [30,31, 44]. This process enables restoring soil extractable P levels that had been temporarily diminished as a result of $\mathrm{P}$ uptake by the crop.

Analyses of soil $\mathrm{pH}$ showed that there were no significant differences between control and treatments and that there was no effect of the fertiliser type, the application rate, or the interaction fertiliser rate $\times$ fertiliser type ( $P$ values $>0.05)$. Therefore, changes in soil extractable $\mathrm{P}$ cannot be explained by differences in soil $\mathrm{pH}$ between fertiliser treatments. Soil organic matter was also measured but there were no significant differences between control and treatments $(P=0.82)$.

3.2.3. Soil Exchangeable Potassium. Overall, there were significant differences in soil exchangeable $\mathrm{K}$ between control and treatments $(P=0.04)$, and there was a significant effect of the fertiliser type $(P=0.02)$. All fertiliser treatments showed a small decline in soil $\mathrm{K}$ Index from 3, as recorded for the control at the start of the experiment, to $2+[28]$. The decline in soil exchangeable $\mathrm{K}$ occurred to a greater extent in ureatreated plots which showed a relatively lower value $(153 \mathrm{mg}$ $\left.\mathrm{kg}^{-1}\right)$ compared with the control $\left(201 \mathrm{mg} \mathrm{kg}^{-1}\right) \cdot \mathrm{OMF}_{10}$ and $\mathrm{OMF}_{15}$ showed intermediate levels of soil exchangeable $\mathrm{K}$ (166 and $168 \mathrm{mg} \mathrm{kg}^{-1}$, resp.) between the control and the plots treated with biosolids granules $\left(180 \mathrm{mg} \mathrm{kg}^{-1}\right)$. There was no effect of the fertiliser application rate $(P=0.06)$ but soil exchangeable $\mathrm{K}$ decreased approximately $10 \%$ more in plots that received $250 \mathrm{~kg} \mathrm{ha}^{-1}$ of $\mathrm{N}$ compared to those at $150 \mathrm{~kg} \mathrm{ha}^{-1}$ of $\mathrm{N}$. These results explain differences in $\mathrm{K}$ uptake by the grass crop as a result of the fertiliser treatment and reflect the positive interaction that exists between nitrogen and potassium [41]. A higher $\mathrm{N}$ application rate combined with increased $\mathrm{N}$ availability in the fertiliser applied (e.g., urea at $250 \mathrm{~kg} \mathrm{ha}^{-1}$ of $\mathrm{N}$ ) enhanced biomass production and $\mathrm{K}$ uptake; hence, soil exchangeable $\mathrm{K}$ recorded a lower value in the analyses. The above is possible because of the satisfactory soil $\mathrm{K}$ Index observed at the start of the experiment.

For OMF-treated grass, the supply of $\mathrm{K}$ with the fertiliser offsets, to a greater extent than urea, the decline in soil exchangeable K despite the relatively high DMY levels observed (Table 1). The soil application of $\mathrm{K}$ with biosolids was negligible given its low concentration in the material $[5,18]$. However, DMY was restricted by the availability of $\mathrm{N}$ contained in the biosolids; hence, $\mathrm{K}$ uptake was reduced and the levels detected in the soil analyses remained closer to the initial values. The same mechanism of reduced uptake holds true for the unfertilised (control) grass crop. The trends observed in soil exchangeable $\mathrm{K}$ levels that resulted from the fertiliser treatment may be monitored in the longer term. Because the efficiency of applied fertiliser $\mathrm{N}$ is significantly affected by the availability of soil $\mathrm{K}$, this becomes an important consideration in situations where crop management practices do not include applications of $\mathrm{K}$ fertilisers [39].

\section{Conclusions}

The $\mathrm{OMF}_{10}$ and $\mathrm{OMF}_{15}$ formulations are suitable for application in grass crops. Agronomic efficiency calculations demonstrated the improved performance of the grass crop treated with OMF compared with biosolids granules and showed that they were comparable to those of the grass treated with a straight $\mathrm{N}$ source. This means that the efficiency of nutrient uptake from applied OMF is comparable to that of a mineral $\mathrm{N}$ fertiliser despite the organic nature of the material. The response curves to the application of OMF$\mathrm{N}$ showed average increments in dry matter which were approximately within the range reported in the literature for straight $\mathrm{N}$ fertilisers. The optimum $\mathrm{N}$ application rates with OMF were within $10 \%$ difference compared with urea and consistently lower than biosolids. This has implications from the economic and environmental perspectives in regards to the cost of field spreading and the $\mathrm{N}$ load on the environment.

The suggested fertilisation strategy should not induce significant changes in soil extractable P levels; hence, soil P Index should not be affected. End users such as farmers will find that OMF has a demonstrable advantage compared with biosolids when the materials are applied on soils which have 
satisfactory P levels. The wastewater industry will be able to convert sludge into balanced fertilisers that has potential to meet long-term recycling targets in areas close to production. Therefore, the conversion of biosolids into nutrient-balanced organomineral fertilisers offers an opportunity for improved resource efficiency to deliver some of the agronomic, economic, and environmental benefits associated with recycling.

\section{Acknowledgments}

This research received funding from the European Union Seventh Framework Programme (FP7-ENV.2010.3.1.1-2 ENV) under grant agreement no. 265269 (http://www.endo-sludg.eu/). The article represents the opinion of the authors and does not necessarily represent the view of the European Union or United Utilities Group PLC. The authors are grateful to United Utilities Group PLC, The Engineering and Physical Science Research Council, and Cranfield University for financial and operational support. Help received from $S$. F. Tyrrel, P. Bellamy, R. J. Walker, and the staff at the Soil and Water Laboratory (Cranfield University) is appreciated.

\section{References}

[1] Council of the European Communities, "Council Directive concerning the protection of water against pollution caused by nitrates from agricultural sources. Council Directive of 31 December 1991 (91/676/EEC)," Official Journal of the European Communities, vol. L375, pp. 1-5, 1991.

[2] European Commission, "Environment: sewage sludge," 2012, http://ec.europa.eu/environment/waste/sludge/index.htm.

[3] Department for Environment, Food, and Rural Affairs, Sewage Treatment in the UK: UK Implementation of the EC Urban Waste Water Treatment Directive, PB 6655. DEFRA Publications, London, UK, 2002.

[4] D. Edge, "Perspectives for nutrient removal from sewage and implications for sludge strategy," Environmental Technology, vol. 20, no. 7, pp. 759-763, 1999.

[5] D. L. Antille, Formulation, utilisation and evaluation of organomineral fertilisers [Engineering Doctorate thesis], Cranfield University, Cranfield, UK, 2011.

[6] J. Petts, "Incineration as a waste management option," in Waste Incineration and the Environment, R. E. Hester and R. M. Harrison, Eds., Royal Society of Chemistry, Cambridge, UK, 1994.

[7] P. J. Moseley, T. H. Misselbrook, B. F. Pain, R. Earl, and R. J. Godwin, "The effect of injector tine design on odour and ammonia emissions following injection of bio-solids into arable cropping," Journal of Agricultural Engineering Research, vol. 71, no. 4, pp. 385-394, 1998.

[8] Council of the European Communities, "Council Directive 99/31/EC of 26 April 1999 on the landfill of waste," Official Journal of the European Communities, vol. L182, pp. 1-19, 1999.

[9] L. E. Sommers, "Chemical composition of sewage sludges and analysis of their potential use as fertilizers," Journal of Environmental Quality, vol. 6, no. 2, pp. 225-232, 1977.

[10] W. Bowden and M. J. Hann, "The availability of nitrogen following topsoil application of liquid digested sludge," Nutrient Cycling in Agroecosystems, vol. 47, no. 2, pp. 167-172, 1996.
[11] S. I. Torri and R. S. Corrêa, "Downward movement of potentially toxic elements in biosolids amended soils," Applied and Environmental Soil Science, vol. 2012, Article ID 145724, 7 pages, 2012.

[12] R. D. Davis, "The impact of EU and UK environmental pressures on the future of sludge treatment and disposal," Journal of the Chartered Institution of Water and Environmental Management, vol. 10, no. 1, pp. 65-69, 1996.

[13] R. S. Zeigler and S. Mohanty, "Support for international agricultural research: current status and future challenges," New Biotechnology, vol. 27, no. 5, pp. 565-572, 2010.

[14] C. H. McAllister, P. H. Beatty, and A. G. Good, "Engineering nitrogen use efficient crop plants: the current status," Plant Biotechnology Journal, vol. 10, no. 9, pp. 1011-1025, 2012.

[15] Cabinet Office, Food Matters-Towards a Strategy for the 21st Century, The Cabinet Office, London, 2008, http://webarchive. nationalarchives.gov.uk/+/http:/www.cabinetoffice.gov.uk/me$\mathrm{dia} /$ cabinetoffice/strategy/assets/food/food_mattersl.pdf.

[16] C. J. Dawson and J. Hilton, "Fertiliser availability in a resourcelimited world: production and recycling of nitrogen and phosphorus," Food Policy, vol. 36, no. 1, pp. S14-S22, 2011.

[17] R. A. Fischer, D. Byerlee, and G. O. Edmeades, "Can technology deliver on the yield challenge to 2050? FAO: Economic and Social Development Department. Expert Meeting on How to Feed the World in 2050," 2009, ftp://ftp.fao.org/docrep/fao/ 012/ak977e/ak977e00.pdf.

[18] D. L. Antille, R. Sakrabani, S. F. Tyrrel, M. S. Le, and R. J. Godwin, "Characterisation of organomineral fertilisers derived from nutrient-enriched biosolids granules," Applied and Environmental Soil Science, vol. 2013, Article ID 694597, 11 pages, 2013.

[19] Meteorological Office, "Historic station data," 2010, http://www .metoffice.gov.uk/climate/uk/stationdata/.

[20] D. W. King, Soils of the Luton and Bedford Districts: A Reconnaissance Survey, The Soil Survey of England and Wales, Harpenden, UK, 1969.

[21] D. L. Antille, R. Sakrabani, and R. J. Godwin, "Nitrogen and phosphorus availability following topsoil application of organomineral fertilisers (OMF)," ASABE, vol. 5, pp. 4134-4150, 2012.

[22] L. P. Smith and B. D. Trafford, "Climate and drainage. Ministry of Agriculture, Fisheries and Food," Technical Bulletin No 34, The Stationery Office, London, UK, 1976.

[23] Ministry of Agriculture, Fisheries and Food, The Analysis of Agricultural Materials, Reference Book 427, The Stationery Office, London, UK, 3rd edition, 1986.

[24] P. E. Sparrow, "The comparison of five response curves for representing the relationship between the annual dry-matter, yield of grass herbage and fertilizer nitrogen," The Journal of Agricultural Science, vol. 93, no. 3, pp. 513-520, 1979.

[25] J. Morrison, M. V. Jackson, and P. E. Sparrow, "The response of perennial ryegrass to fertilizer nitrogen in relation to climate and soil," Report of the Joint ADAS/GRI Grassland Manuring Trial GM20. Grassland Research Institute Technical Report No. 27, GRI, Hurley, Berkshire, UK, 1980.

[26] K. G. Cassman, S. Peng, D. C. Olk et al., "Opportunities for increased nitrogen-use efficiency from improved resource management in irrigated rice systems," Field Crops Research, vol. 56, no. 1-2, pp. 7-38, 1998.

[27] A. E. Johnston and P. R. Poulton, Nitrogen in Agriculture: An Overview and Definitions of Nitrogen Use Efficiency, Proc. No. 651, The International Fertiliser Society, York, UK, 2009. 
[28] Department for Environment, Food and Rural Affairs, Fertiliser Manual, Reference Book 209, The Stationery Office, London, UK, 8th edition, 2010.

[29] British Standards EN 13654-2, Soil Improvers and Growing Media. Determination of Nitrogen, Dumas Method. Equivalent to ISO 5725:1994, The British Standards Institution, London, UK, 2001.

[30] S. R. Olsen, C. V. Cole, F. S. Watanabe, and L. A. Dean, "Estimation of available phosphorus in soils by extraction with sodium bicarbonate," USDA Circular No. 939, 1954.

[31] British Standard 7755 Section 3.6, Determination of Phosphorus: Spectrometric Determination of Phosphorus Soluble in Sodium Hydrogen Carbonate Solution., Equivalent to ISO 11263:1994, The British Standards Institution, London, UK, 1995.

[32] GenStat, GenStat Release 14.1, VSN International, Hemel Hempstead, UK, 14th edition, 2011.

[33] P. McFeely and D. MacCarthy, "Effect of time on initial spring grazing and nitrogen use on pasture production," Irish J. of Agricultural Research, vol. 20, no. 2-3, pp. 137-146, 1981.

[34] M. O’Donovan, L. Delaby, G. Stakelum, and P. Dillon, "Effect of autumn/spring nitrogen application date and level on dry matter production and nitrogen efficiency in perennial ryegrass swards," Irish Journal of Agricultural and Food Research, vol. 43, no. 1, pp. 31-41, 2004.

[35] P. D. Penning, A. J. Parsons, R. J. Orr, and T. T. Treacher, "Intake and behaviour responses by sheep to changes in sward characteristics under continuous stocking," Grass and Forage Science, vol. 46, no. 1, pp. 15-28, 1991.

[36] C. J. Watson, R. J. Stevens, M. K. Garrett, and C. H. McMurray, "Efficiency and future potential of urea for temperate grassland," Fertilizer Research, vol. 26, no. 1-3, pp. 341-357, 1990.

[37] R. Sylvester-Bradley, "Scope for more efficient use of fertilizer nitrogen," Soil Use and Management, vol. 9, no. 3, pp. 112-117, 1993.

[38] R. J. Skinner and A. D. Todd, "Twenty-five years of monitoring $\mathrm{pH}$ and nutrient status of soils in England and Wales," Soil Use and Management, vol. 14, no. 3, pp. 162-169, 1998.

[39] A. E. Johnston, P. R. Poulton, C. J. Dawson, and M. J. Crawley, Inputs of Nutrients and Lime for the Maintenance of Fertility of Grasslands Soils, Proc. No. 486, The International Fertiliser Society, York, UK, 2001.

[40] A. E. Johnston, "The value of long-term field experiments in agricultural, ecological, and environmental research," Advances in Agronomy, vol. 59, no. C, pp. 291-333, 1997.

[41] A. E. Johnston and G. F. J. Milford, Potassium and Nitrogen Interactions in Crop Production, Proc. No. 615, The International Fertiliser Society, York, UK, 2007.

[42] C. J. Dawson, "Phosphate and potash - reconsidering their importance and use," Journal of the Royal Agricultural Society of England, vol. 172, pp. 1-9, 2011.

[43] M. C. H. Mouat and P. Nes, "Effect of the interaction of nitrogen and phosphorus on the growth of ryegrass," New Zealand Journal of Agricultural Research, no. 3, pp. 333-336, 1983.

[44] A. E. Johnston and J. K. Syers, Changes in Understanding the Behaviour of Soil and Fertiliser Phosphorus: Implications for Their Efficient Use in Agriculture, Proc. No. 589, The International Fertiliser Society, York, UK, 2006. 

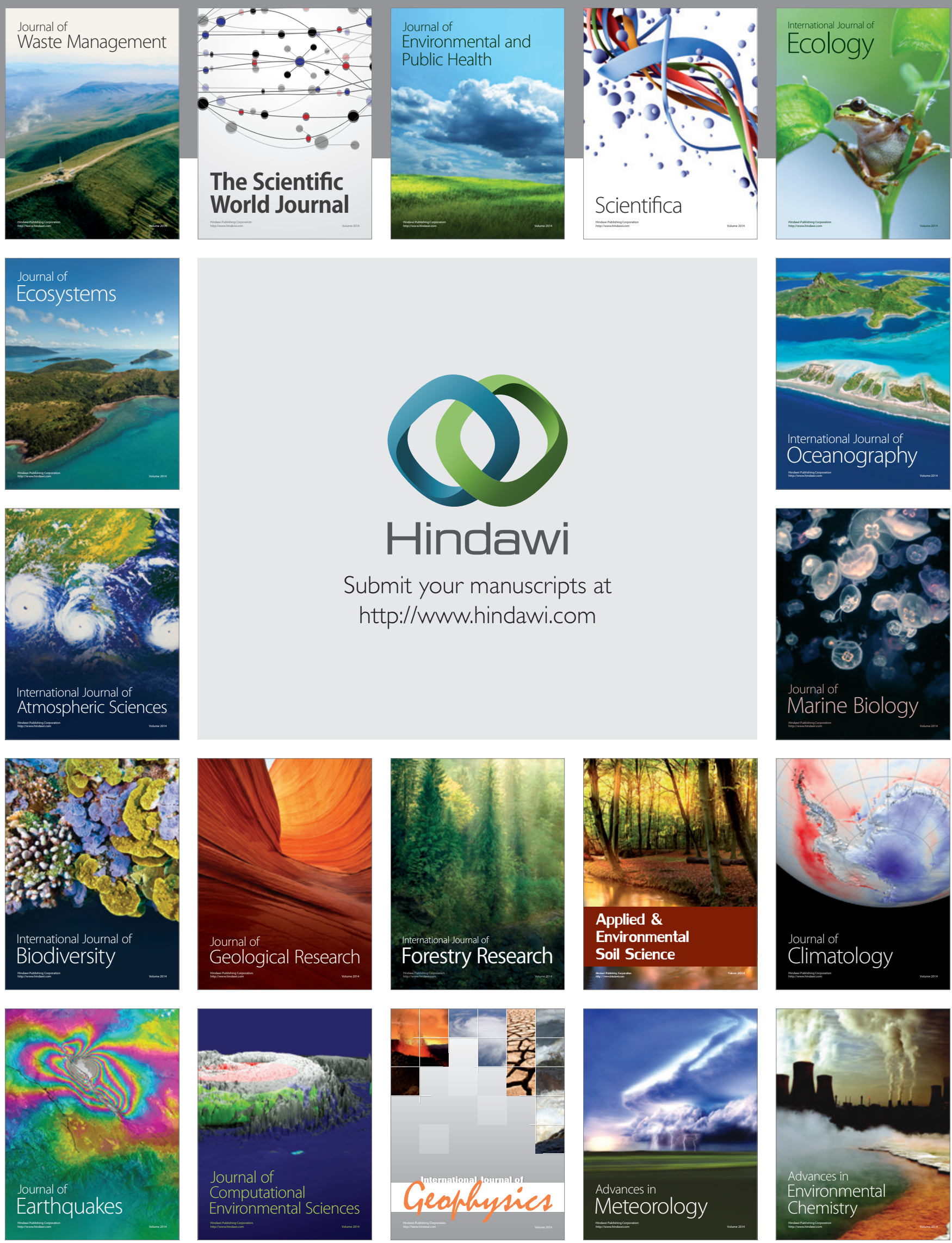